\title{
Reversible bacterial immobilization based on the salt-dependent adhesion of the bacterionanofiber protein AtaA
}

\author{
Shogo Yoshimoto, Yuki Ohara, Hajime Nakatani and Katsutoshi Hori *i]
}

\begin{abstract}
Background: Immobilization of microbial cells is an important strategy for the efficient use of whole-cell catalysts because it simplifies product separation, enables the cell concentration to be increased, stabilizes enzymatic activity, and permits repeated or continuous biocatalyst use. However, conventional immobilization methods have practical limitations, such as limited mass transfer in the inner part of a gel, gel fragility, cell leakage from the support matrix, and adverse effects on cell viability and catalytic activity. We previously showed a new method for bacterial cell immobilization using AtaA, a member of the trimeric autotransporter adhesin family found in Acinetobacter sp. Tol 5. This approach is expected to solve the drawbacks of conventional immobilization methods. However, similar to all other immobilization methods, the use of support materials increases the cost of bioprocesses and subsequent waste materials.
\end{abstract}

Results: We found that the stickiness of the AtaA molecule isolated from Tol 5 cells is drastically diminished at ionic strengths lower than $10 \mathrm{mM}$ and that it cannot adhere in deionized water, which also inhibits cell adhesion mediated by AtaA. Cells immobilized on well plates and polyurethane foam in a salt solution were detached in deionized water by rinsing and shaking, respectively. The detached cells regained their adhesiveness in a salt solution and could rapidly be re-immobilized. The cells expressing the ataA gene maintained their adhesiveness throughout four repeated immobilization and detachment cycles and could be repeatedly immobilized to polyurethane foam by a 10-min shake in a flask. We also demonstrated that both bacterial cells and a support used in a reaction could be reused for a different type of reaction after detachment of the initially immobilized cells from the support and a subsequent immobilization step.

Conclusions: We invented a unique reversible immobilization method based on the salt-dependent adhesion of the AtaA molecule that allows us to reuse bacterial cells and supports by a simple manipulation involving a deionized water wash. This mitigates problems caused by the use of support materials and greatly helps to enhance the efficiency and productivity of microbial production processes.

Keywords: Immobilization, Whole-cell catalyst, Trimeric autotransporter adhesin, Acinetobacter

\section{Background}

Although microbial cells are expected to provide environmentally friendly production processes as whole-cell biocatalysts with highly effective and selective reactivity under ordinary temperatures and pressures [1-5], their

\footnotetext{
*Correspondence: khori@chembio.nagoya-u.ac.jp

Department of Biomolecular Engineering, Graduate School

of Engineering, Nagoya University, Furo-cho, Chikusa-ku,

Nagoya 464-8603, Japan
}

disadvantages, such as complicated handling due to their fragility, a requirement for costly product separation processes, and easy inactivation at unsuitable temperatures, $\mathrm{pH}$, and substrate and product concentrations, raise production costs and hinder their commercial use in chemical production processes. To expand the use of microbial production processes in the industrial sector, it is important to improve the efficiency of the entire process, from an upstream process including strain development to a 
downstream process including product separation [6]. Recently, a systems metabolic engineering approach targeting an upstream process received considerable attention by aiming to develop a novel biosynthetic pathway producing high-value products and/or improve their productivity in microbial cells [6-11]. As for the downstream process, cell immobilization is important because it simplifies product separation, enables the cell concentration to be increased, stabilizes the enzymatic activity, and permits repetitive or continuous use of precious and expensive biocatalysts [12-15]. Conventional methods for cell immobilization are gel entrapment, covalent bonding to solid surfaces, cross-linkage, and physical adsorption $[16,17]$. These methods, however, have practical limitations, such as limited mass transfer in the inner part of a gel $[18,19]$, gel fragility, cell leakage from the support matrix, and adverse effects on cell viability and catalytic activity [12].

We previously invented a method for bacterial cell immobilization using the adhesive protein AtaA found in Acinetobacter sp. Tol 5 [20-22], which belongs to the trimeric autotransporter adhesin (TAA) family [23]. Although AtaA shares a fibrous architecture consisting of an N-terminus-passenger domain (PSD) containing head and stalk domains - transmembrane anchor (TM) C-terminus with TAA family members [24], which usually bind to target biotic surfaces, AtaA uniquely confers nonspecific high adhesiveness to both abiotic and biotic surfaces on bacterial cells transformed with its gene. Large amounts of growing, resting, even lyophilized transformant cells can be quickly and firmly immobilized onto any material surfaces selected according to the application [25]. Cells immobilized directly on surfaces through AtaA are not embedded in extracellular polymeric substances with mass transfer limitations, show enhanced tolerance [22], increase chemical reaction rates, and can be repeatedly used in reactions without inactivation [25]. However, similar to all other immobilization methods, the use of support materials increases the cost of bioprocesses and subsequent waste materials. These might be inevitable problems as long as support materials are used in the immobilization process. A way to minimize these drawbacks should be developed so as to, for example, reduce the amount of support materials, use inexpensive materials or waste materials, and reuse support materials.

AtaA is a homotrimer of polypeptides comprising 3630 amino acids. In a previous study, we developed a method to isolate its PSD, which is secreted to the bacterial cell surface through the TM and is responsible for biological functions, by genetically introducing a recognition site for human rhinovirus 3C (HRV 3C) protease [26]. Specific cleavage by the protease reaps AtaA PSD nanofibers $225 \mathrm{~nm}$ in length from the cell surface. This enables biochemical and biophysical analyses of the purified huge AtaA PSD in the native molecular state. Here, we demonstrate a new phenomenon: AtaA PSD cannot adhere to surfaces in deionized water $\left(\mathrm{dH}_{2} \mathrm{O}\right)$. Based on this molecular property of AtaA, we developed a unique method for the reversible immobilization of bacterial cells, which can solve the problems caused by the use of support materials.

\section{Results \\ Effect of ionic strength on the adhesive property of the AtaA molecule}

To investigate the adhesive property of the AtaA molecule, AtaA PSD was isolated by the enzymatic reaping method from a Tol 5 derivative strain, 4140, transformed with p3CAtaA $[26,27]$. $\mathrm{KCl}$ solutions $(50 \mu \mathrm{L})$ of various concentrations containing $5 \mu \mathrm{g} / \mathrm{mL}$ of the purified AtaA PSD were incubated in 96-well polystyrene (PS) and glass plates at $28^{\circ} \mathrm{C}$ for $2 \mathrm{~h}$. The protein solution was removed from each well using a micropipette and the well was rinsed three times with $200 \mu \mathrm{L}$ of phosphate-buffered saline containing $0.05 \%$ Tween-20 (PBS-T). The AtaA PSD adsorbed to the well plates was assessed by ELISA. Interestingly, we found that the amounts of AtaA PSD molecules adsorbed onto surfaces of hydrophobic PS and hydrophilic glass dropped sharply at ionic strengths lower than $10 \mathrm{mM}$, with the molecules hardly adhering in $\mathrm{dH}_{2} \mathrm{O}$, despite their high adhesiveness at higher ionic strengths (Fig. 1a). AtaA PSD cannot be considered to be denatured in $\mathrm{dH}_{2} \mathrm{O}$ because AtaA PSD has high structural stability [26, 28]. Indeed, AtaA PSD molecules isolated from cells by the enzymatic reaping method mentioned above were dissolved in $\mathrm{dH}_{2} \mathrm{O}$, and subsequently $\mathrm{KCl}$ solution was added to the adherence assay to attain the final ionic strengths intended. Furthermore, by using a quartz crystal microbalance (QCM), which enables the quantification of molecules adhered to its quartz crystal sensor chip as a frequency shift, we confirmed that the adhesiveness of AtaA PSD can be recovered in a salt solution by adding $\mathrm{KCl}$ salt to fresh water. AtaA PSD molecules did not adhere to a gold-coated sensor chip of QCM in $\mathrm{dH}_{2} \mathrm{O}$, but started adhering to the chip immediately after $\mathrm{KCl}$ solution was added (Fig. 1b). Evidently, AtaA PSD is not denatured in $\mathrm{dH}_{2} \mathrm{O}$ and recovers its adhesiveness in a salt solution.

\section{Effect of the ionic strength on bacterial cell adhesion mediated by AtaA}

The identification of the ionic strength-dependent stickiness of the AtaA PSD prompted us to examine whether or not bacterial cell adhesion mediated by AtaA also depends on ionic strength. Tol 5 cells were grown, 

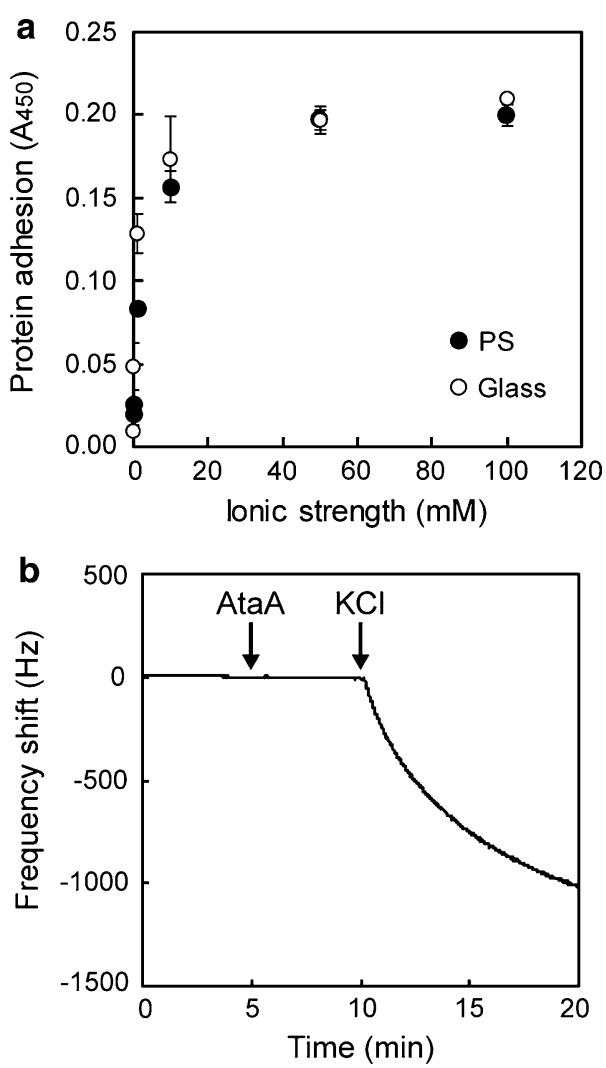

Fig. 1 Effect of ionic strength on the adhesion of purified AtaA PSD. a Adhesion of AtaA PSD as a function of ionic strength. Amounts of AtaA PSD adhered to wells of a polystyrene (PS) or a glass 96-well plate were quantified by ELISA with anti-AtaA antiserum. Data are expressed as mean \pm SEM $(n=3)$. b lon-dependent adhesion of AtaA PSD was analyzed using QCM. Arrows indicate the addition of AtaA PSD dissolved in $\mathrm{dH}_{2} \mathrm{O}$ and $\mathrm{KCl}$ solution

harvested, washed with $\mathrm{dH}_{2} \mathrm{O}$, suspended in $\mathrm{dH}_{2} \mathrm{O}$ and $\mathrm{KCl}$ solutions of various concentrations at an $\mathrm{OD}_{660}$ of 0.5 , and placed into 96-well plates. After a 2-h incubation at $28{ }^{\circ} \mathrm{C}$ without shaking, the cell suspension was removed from each well by a micropipette and the well was rinsed three times with $200 \mu \mathrm{L}$ of $\mathrm{dH}_{2} \mathrm{O}$ or $\mathrm{KCl}$ solution of each concentration using a micropipette. The cells immobilized onto the well surfaces were quantified by crystal violet staining. At ionic strengths higher than $20 \mathrm{mM}$, a large amount of Tol 5 cells was immobilized onto PS and glass surfaces, although the amount gradually increased as the ionic strength increased (Fig. 2a). However, Tol 5 cell adhesion dropped at ionic strengths lower than $5 \mathrm{mM}$ for both PS and glass surfaces, and Tol 5 cells were unable to adhere to either surface in $\mathrm{dH}_{2} \mathrm{O}$. To confirm that such ionic strength-dependent adhesion of bacterial cells can be decisively attributed to the adhesive properties of the AtaA molecule, the cell adhesion
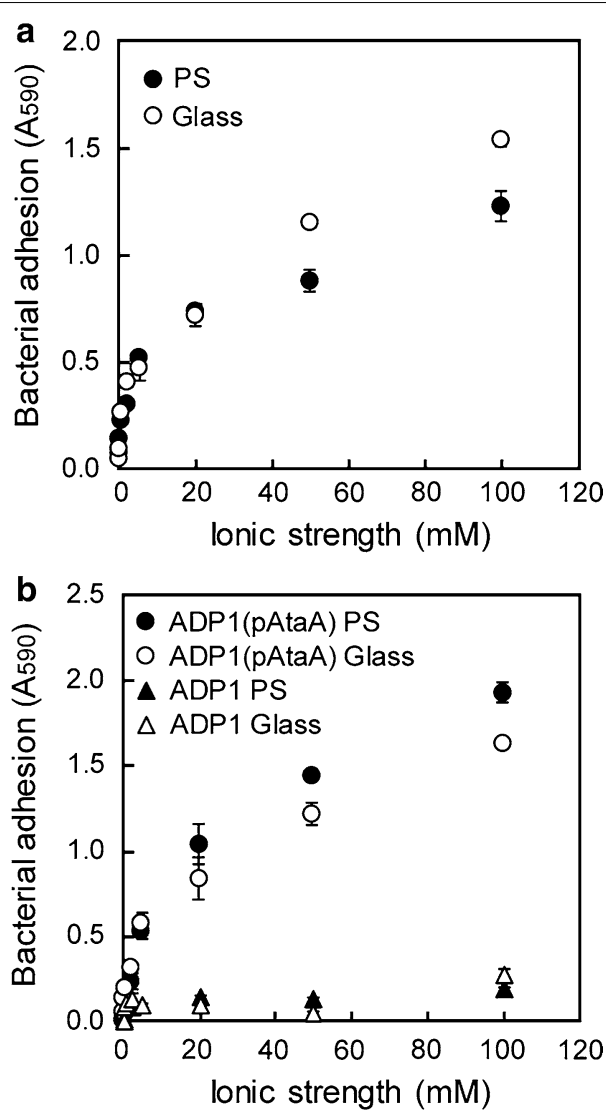

Fig. 2 Effect of ionic strength on the adhesion of bacterial cells to material surfaces. a Adhesion of Tol 5 cells as a function of ionic strength. Tol 5 cells adhering to wells of a PS or a glass 96 -well plate were quantified by crystal violet staining. b Adhesion of ADP1 and derivative cells as a function of ionic strength. ADP1 wild-type and ADP1 (pAtaA) cells adhering to the wells of a PS or a glass 96-well plate were quantified by crystal violet staining. Data are expressed as mean $\pm \operatorname{SEM}(n=3)$

of Acinetobacter baylyi ADP1 and its transformant with ataA, ADP1 (pAtaA), to PS and glass surfaces was examined at various ionic strengths by the same procedure used for Tol 5 cells. ADP1 cells expressing AtaA showed high adhesiveness to both PS and glass surfaces at ionic strengths higher than $20 \mathrm{mM}$ with a gradual increase in adhesion with ionic strength, whereas wild-type ADP1 was hardly immobilized at any ionic strength (Fig. 2b). However, at an ionic strength lower than $5 \mathrm{mM}$, even ADP1 cells expressing AtaA showed the same diminished adhesion as Tol 5 cells, adhering to neither PS surface nor glass surface in $\mathrm{dH}_{2} \mathrm{O}$. Therefore, the adhesion profiles of Tol 5 cells and ADP1 (pAtaA) cells at various ionic strengths directly reflect the properties of the AtaA molecule. 
Cell detachment and reversible immobilization using AtaA Our finding that the cell adhesion mediated by AtaA is inhibited by $\mathrm{dH}_{2} \mathrm{O}$ prompted us to examine the ability of a simple $\mathrm{dH}_{2} \mathrm{O}$ wash to detach bacterial cells already immobilized on material surfaces. After immobilization of ADP1 (pAtaA) cells onto the well surfaces in $100 \mathrm{mM}$ $\mathrm{KCl}$ solution as described above, the wells were rinsed with $200 \mu \mathrm{L}$ of $\mathrm{dH}_{2} \mathrm{O}$ or $100 \mathrm{mM} \mathrm{KCl}$ solution using a micropipette. This washing step was repeated three times. Thereafter, the cells still immobilized on the well surfaces were quantified by crystal violet staining. Most of the cells washed with $\mathrm{dH}_{2} \mathrm{O}$ were detached from both PS and glass surfaces, whereas the cells washed with $100 \mathrm{mM} \mathrm{KCl}$ solution were retained on the surfaces (Fig. 3).

We also confirmed the ability of $\mathrm{dH}_{2} \mathrm{O}$ to detach ADP1 (pAtaA) cells previously immobilized on a polyurethane foam support, which is often used in bioprocesses as a support. The cells were immobilized onto $1-\mathrm{cm}^{3}$ pieces of polyurethane foam support. A piece of the support with the immobilized cells was transferred into fresh $100 \mathrm{mM}$ $\mathrm{KCl}$ solution, gently rinsed, picked up with tweezers, and shaken in $\mathrm{dH}_{2} \mathrm{O}$ or $100 \mathrm{mM} \mathrm{KCl}$ solution for video recording. When shaken in $\mathrm{dH}_{2} \mathrm{O}$, the immobilized cells immediately began to detach and an increase in the turbidity of the surrounding $\mathrm{H}_{2} \mathrm{O}$ solution was observed. An additional movie file shows this in more detail (see Additional file 1). In contrast, the immobilized cells were not detached at all by being shaken in $100 \mathrm{mM} \mathrm{KCl}$ solution (see Additional file 2).

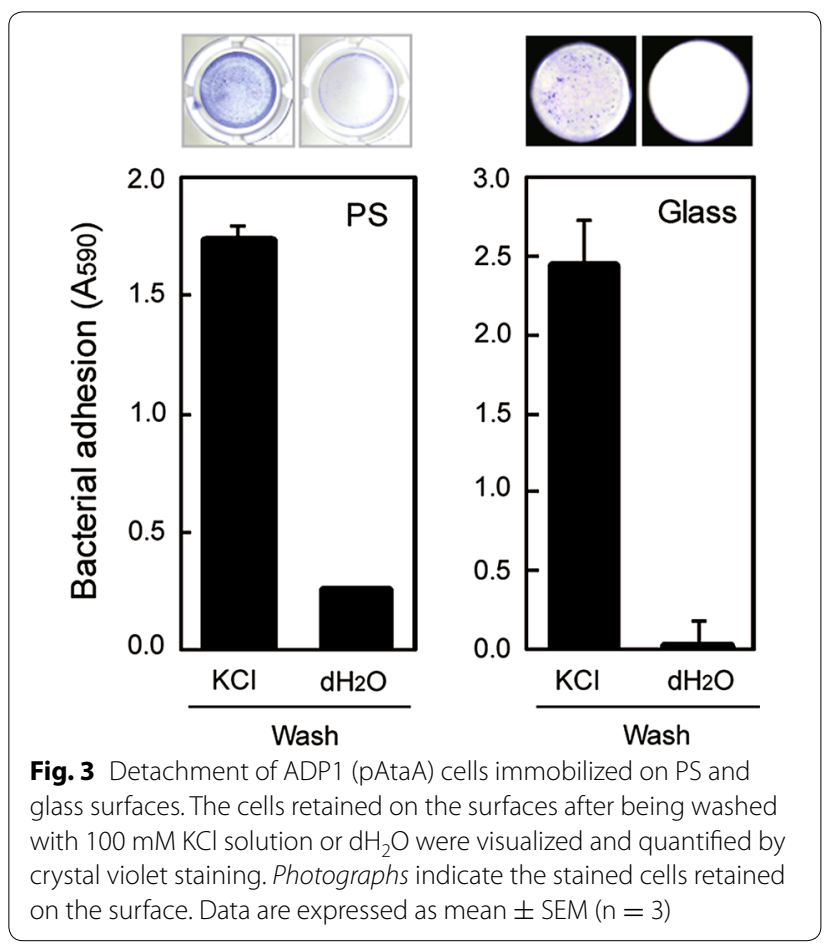

Next, we tried to repeat the immobilization and detachment of bacterial cells expressing AtaA. ADP1 (pAtaA) cells were repeatedly subjected to the immobilization/detachment process; cells suspended in $100 \mathrm{mM}$ $\mathrm{KCl}$ solution were immobilized onto the PS well surface by a 2 -h incubation (immobilization process) and subsequently detached by the $\mathrm{dH}_{2} \mathrm{O}$ wash using the same procedure described above (detachment process). The detached cells were collected by centrifugation, resuspended in $100 \mathrm{mM} \mathrm{KCl}$ solution at an $\mathrm{OD}_{660}$ of 0.5 , and placed into the new well for the next immobilization cycle. This immobilization/detachment process was repeated four times. As shown in Fig. 4a, the detached cells showed the same adhesion ability as the fresh cells used for the first adherence assay, and the cell adhesiveness did not decrease throughout four immobilization/ detachment cycles. The cells finally detached were subjected to flow cytometry to quantify the amount of AtaA displayed on the ADP1 (pAtaA) cell surface. This revealed that the amount of AtaA molecules on the cell surface did not decrease even after the fourth detachment compared with that on fresh cells before the first immobilization (Fig. 4b), suggesting that AtaA was not impaired throughout the repeated detachment manipulations by washing with $\mathrm{dH}_{2} \mathrm{O}$. The ADP1 (pAtaA) cells immobilized in each immobilization/detachment cycle were subjected to an esterase activity assay involving the addition of a reaction buffer containing a substrate directly to the well. The cellbound esterase activity of the immobilized cells on the PS surface was maintained at the same level throughout the four cycles (Fig. 4c), suggesting that the repeated immobilization/detachment cycle also did not deteriorate the integrity of the surface of ADP1 (pAtaA) cells.

We also examined whether or not ADP1 (pAtaA) cells can be reversibly immobilized onto polyurethane foam support. Six pieces of the polyurethane foam $($ a $1 \mathrm{~cm}$ cube) were placed into a $30-\mathrm{mL}$ cell suspension of ADP1 (pAtaA) at an $\mathrm{OD}_{660}$ of 2.0 in a 100-mL Erlenmeyer flask and shaken at $115 \mathrm{rpm}$ for immobilization of the bacterial cells. The percentage of immobilized cells over time is shown in Fig. 4d ("1st"). More than $90 \%$ of the cells were immobilized within $10 \mathrm{~min}$ (immobilization process). Subsequently, the supernatant was discarded by decantation and $30 \mathrm{~mL}$ of $\mathrm{dH}_{2} \mathrm{O}$ was poured into the flask, which was then shaken at $115 \mathrm{rpm}$ for $5 \mathrm{~min}$. This washing step was repeated three times (detachment process). The detached cells from each washing step were collected by centrifugation and resuspended in $100 \mathrm{mM} \mathrm{KCl}$ solution at an $\mathrm{OD}_{660}$ of 2.0. Six fresh pieces of the polyurethane foam were placed into the cell suspension for the next immobilization cycle. This immobilization/detachment cycle was also repeated four times. The time profiles of the immobilization were similar throughout the four 

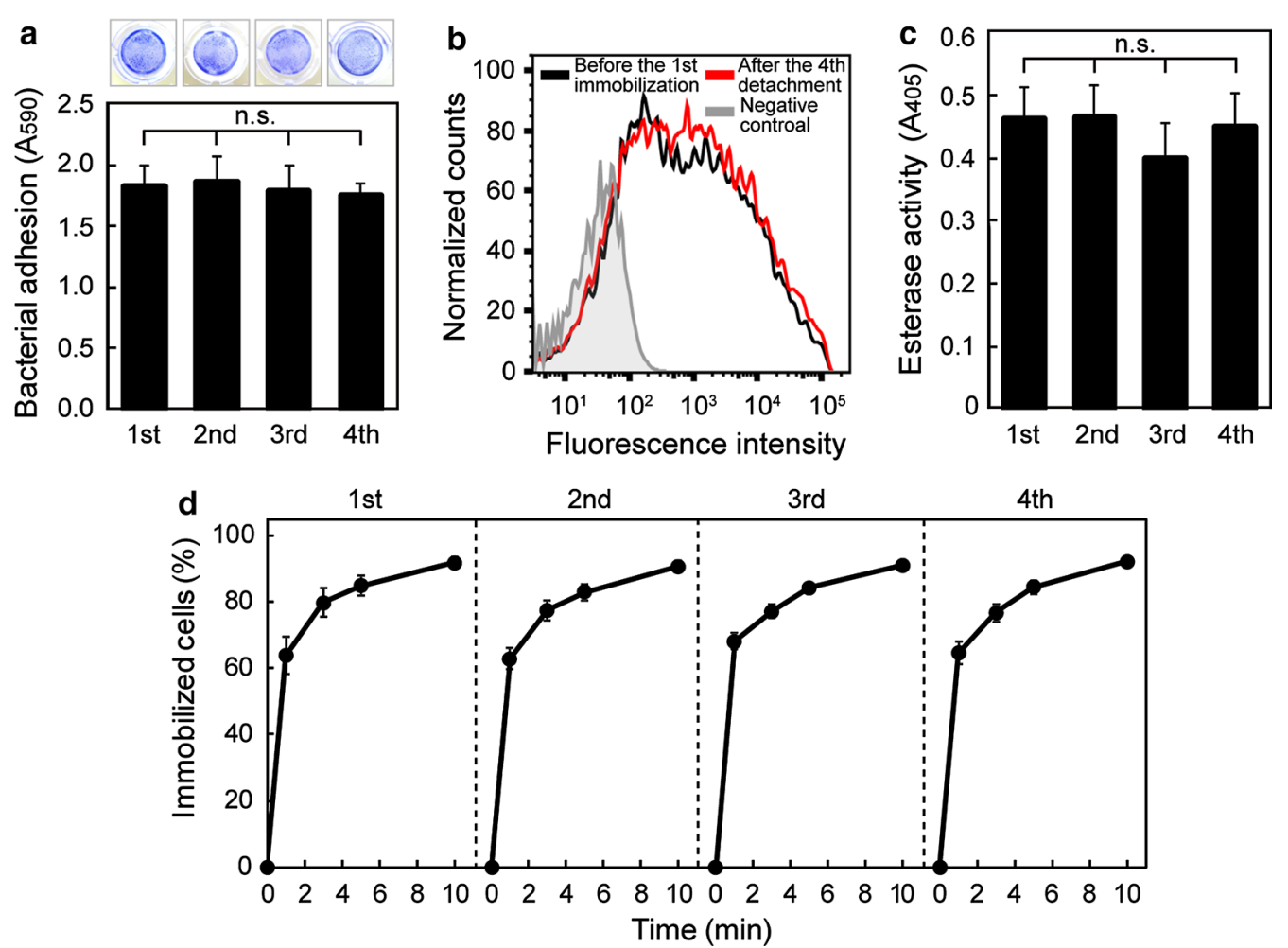

Fig. 4 Re-immobilization of ADP1 (pAtaA) cells. a Repetition of the immobilization/detachment cycle of ADP1 (pAtaA) cells. The cells were immobilized onto well surfaces of a PS plate in $100 \mathrm{mM} \mathrm{KCl}$ solution for $2 \mathrm{~h}$, detached by washing with $\mathrm{dH}_{2} \mathrm{O}$ from the PS plate, collected by centrifugation, resuspended in the $\mathrm{KCl}$ solution, added to fresh wells, and incubated for re-immobilization for $2 \mathrm{~h}$. Immobilized cells were visualized and quantified by crystal violet staining. This process was repeated four times. Photographs indicate the stained cells immobilized on the surface at each cycle. $\mathbf{b}$ AtaA molecules on the ADP1 (pAtaA) cell surface before and after the repetition of the immobilization/detachment cycle were analyzed by flow cytometry. The black and red lines show surface-displayed AtaA before the first immobilization and after the fourth cycle of the repetition, respectively. The wild type of ADP1 without AtaA molecules was subjected to the same analysis as a negative control. c Esterase activities of ADP1 (pAtaA) cells immobilized on the plate wells in $\mathbf{a}$. $\mathbf{d}$ Time course of the immobilization ratio of ADP1 (pAtaA) cells onto the polyurethane support in each immobilization/detachment cycle. In the respective cycles, the cells were immobilized onto polyurethane foam in $100 \mathrm{mM} \mathrm{KCl}$ solution in a flask with shaking and the immobilization ratio was calculated from a decrease in the $\mathrm{OD}_{660}$ of the cell suspension. Data are expressed as mean $\pm \mathrm{SEM}$ $(n=3)$. n.s. not significant (ANOVA, $P>0.1)$

cycles; more than 90\% of ADP1 (pAtaA) cells detached from the polyurethane were re-immobilized onto the fresh polyurethane foam within $10 \mathrm{~min}$ (Fig. 4d).

Thus, we have succeeded in developing a novel method for the reversible immobilization of bacterial cells, which enables the reuse of cells without impairment, by means of AtaA expression and a simple manipulation involving a $\mathrm{dH}_{2} \mathrm{O}$ wash. Other conventional immobilization methods are unsuitable for the development of a reversible process without support destruction or cell inactivation.

\section{Reuse of bacterial cells in a different type of reaction}

To show the merit of our reversible immobilization method, we attempted to demonstrate the reusability of bacterial cells for different types of reactions, an ester hydrolysis and toluene degradation, using the schema shown in Fig. 5a. At first, Tol 5 cells were immobilized onto three pieces of the polyurethane foam support in a 100-mL Erlenmeyer flask containing the cells suspended in $30 \mathrm{~mL}$ of $100 \mathrm{mM} \mathrm{KCl}$ solution $\left(\mathrm{OD}_{660}=1.0\right)$ by shaking at $115 \mathrm{rpm}$ at $28{ }^{\circ} \mathrm{C}$ for $30 \mathrm{~min}$. The cells loosely attaching to the support were removed by dipping them into $100 \mathrm{mM} \mathrm{KCl}$ solution and gentle squeezing. A piece of the support with the immobilized Tol 5 cells was placed into esterase reaction buffer in a test tube. After a 10 -min incubation of the test tube at $28{ }^{\circ} \mathrm{C}$, the reaction buffer turned from colorless to yellow due to the 4-nitrophenol produced by esterase on the immobilized Tol 5 cells (Fig. 5b). Next, three pieces of the support used in the esterase reaction were collected and washed in $100 \mathrm{~mL}$ of $\mathrm{dH}_{2} \mathrm{O}$ in a 500-mL Erlenmeyer flask by shaking at $115 \mathrm{rpm}$ for $5 \mathrm{~min}$. This washing step was repeated three times. The detached cells from each washing step were collected by centrifugation, resuspended in $30 \mathrm{~mL}$ 


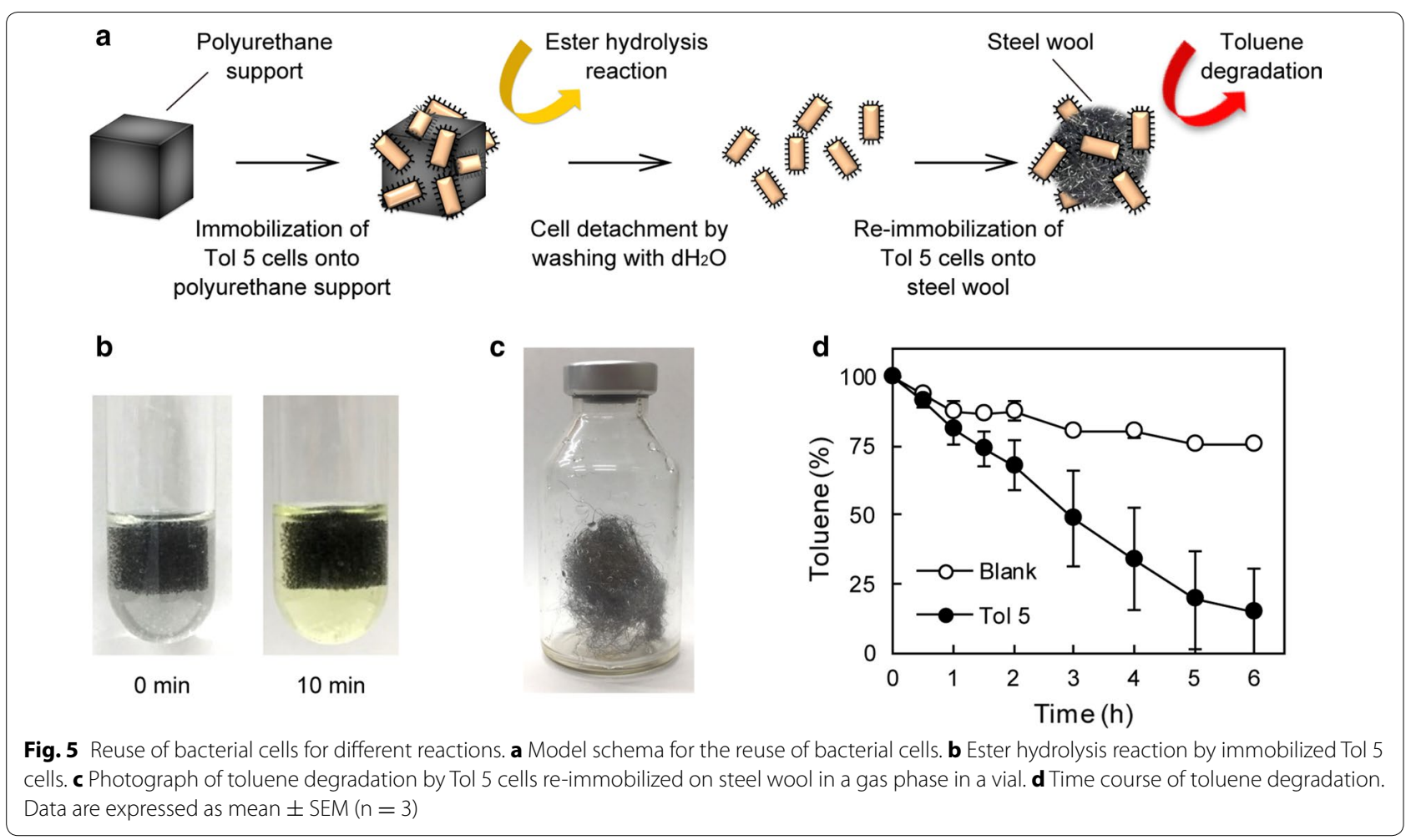

of basal salt (BS) medium in a 100-mL Erlenmeyer flask, and re-immobilized onto $300 \mathrm{mg}$ of steel wool support, which is not eroded by organic solvents, by shaking at $115 \mathrm{rpm}$ for $1 \mathrm{~h}$.

For the induction of toluene-degrading gene expression, the steel wool support with the re-immobilized Tol 5 cells was picked up, touched with paper towel to remove extra water, transferred into a $25-\mathrm{mL}$ vial, and incubated at $28{ }^{\circ} \mathrm{C}$ for 1 day under a toluene atmosphere. After this induction step, the immobilized cells on the steel wool support were subjected to a toluene-degradation reaction in a gas phase (Fig. $5 \mathrm{c}$ ). The reaction was started by injecting $1 \mu \mathrm{L}$ of toluene into the vial, and thereafter the toluene concertation of the gas in the vial was quantified by gas chromatography-mass spectrometry (GC/MS) and its time-dependent decrease was plotted (Fig. 5d). The cells immobilized on the steel wool support linearly degraded toluene for $5 \mathrm{~h}$ and thereafter the degradation rate lowered following the first-order reaction kinetics that depends on the toluene concentration. The slight decrease in the toluene concentration in the control vial without the bacterial cells (blank) suggests adsorption of toluene onto a butyl rubber septum on the cap or solubilization of toluene in a small amount of water from the wetting support. Thus, our reversible immobilization method uniquely allows us to reuse bacterial cells for different types of chemical reactions after detachment from a support, re-immobilization, and an appropriate induction or reactivation for second reaction.

\section{Reuse of supports for a different type of reaction}

To show the further merit of our reversible immobilization method, we attempted to demonstrate the reusability of the support used for the cell immobilization using the schema shown in Fig. 6a. Three pieces of the polyurethane foam support were placed into $30 \mathrm{~mL}$ of the suspension of resting ADP1 (pAtaA) cells in $100 \mathrm{mM} \mathrm{KCl}$ solution $\left(\mathrm{OD}_{660}=1.0\right)$ and shaken in a $100-\mathrm{mL}$ Erlenmeyer flask at $115 \mathrm{rpm}$ at $30{ }^{\circ} \mathrm{C}$ for $30 \mathrm{~min}$. The cells loosely attaching to the support were removed by dipping them into $100 \mathrm{mM} \mathrm{KCl}$ solution and gentle squeezing. A piece of the support with the immobilized ADP1 (pAtaA) cells was placed into an esterase reaction buffer in a test tube. After a 10-min incubation of the test tube at $28{ }^{\circ} \mathrm{C}$, the reaction buffer turned from colorless to yellow due to the 4-nitrophenol produced by esterase on the immobilized ADP1 (pAtaA) cells, as with the Tol 5 cells (Fig. 6b).

Three pieces of the support used in the reaction were collected and washed in $100 \mathrm{~mL}$ of $\mathrm{dH}_{2} \mathrm{O}$ in a $500-\mathrm{mL}$ Erlenmeyer flask by shaking at $115 \mathrm{rpm}$ for $10 \mathrm{~min}$. This washing step was repeated three times to thoroughly remove ADP1 (pAtaA) cells. Subsequently, three pieces of the used support were transferred into $30 \mathrm{~mL}$ of a 


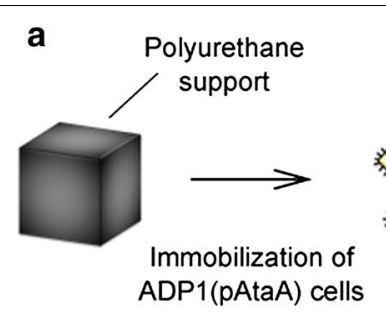

b

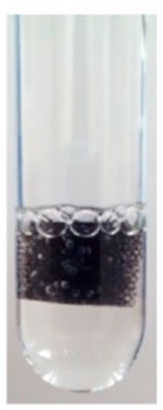

$0 \mathrm{~min}$

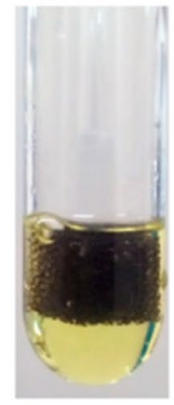

$10 \mathrm{~min}$

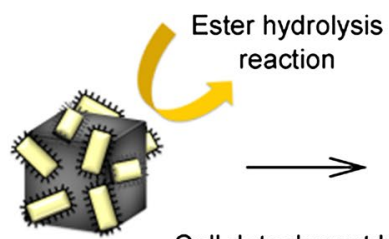

Cell detachment by washing with $\mathrm{dH}_{2} \mathrm{O}$

C

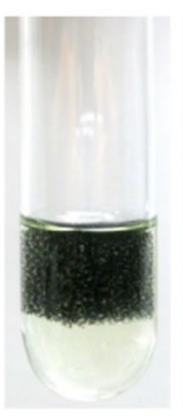

Blank

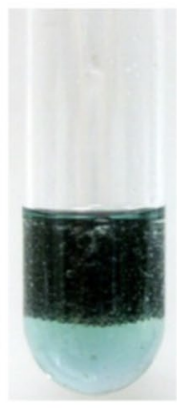

Pristine

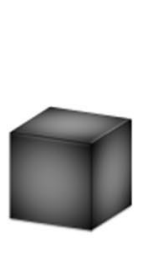

Immobilization of ST-550(pAtaA) cells
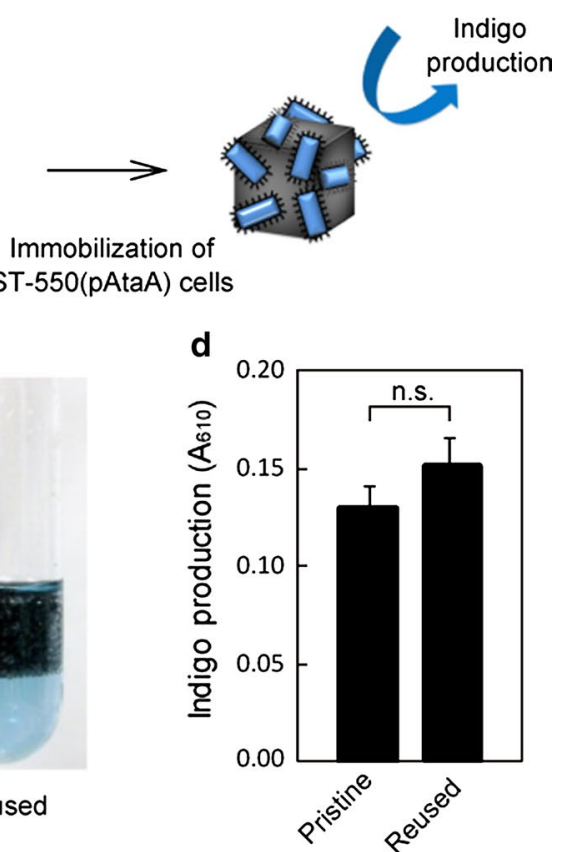

Fig. 6 Reuse of supports for different reactions. a Model schema for the reuse of supports with two different bacterial strains. b Ester hydrolysis reaction by immobilized ADP1 ( $\mathrm{pAtaA}$ ) cells. c Indigo production by immobilized ST-550 ( $\mathrm{pAtaA}$ ) cells. d Quantification of indigo production by ST-550 (pAtaA) cells immobilized onto pristine or reused polyurethane supports in c. Data are expressed as mean \pm SEM ( $n=3$ ). $n$.S. not significant $(t$ test, $P>0.1)$

suspension of resting cells of Acinetobacter sp. ST-550 transformed with ataA, ST-550 (pAtaA) [22], which has the ability to produce indigo from indole using its phenol hydroxylase [29, 30], in $100 \mathrm{mM} \mathrm{KCl}$ solution $\left(\mathrm{OD}_{660}=1.0\right)$ and shaken in a $100-\mathrm{mL}$ Erlenmeyer flask at $115 \mathrm{rpm}$ at $30{ }^{\circ} \mathrm{C}$ for $30 \mathrm{~min}$ for cell immobilization. Pristine pieces of the polyurethane foam support were also subjected to the cell immobilization for a control experiment. The cells loosely attaching to the support were removed by dipping them into $100 \mathrm{mM} \mathrm{KCl} \mathrm{solu-}$ tion and gentle squeezing. Each piece of the support with the immobilized ST-550 (pAtaA) cells was placed into an indigo reaction solution and incubated for $12 \mathrm{~h}$. Indigo produced by the immobilized ST-550 (pAtaA) was extracted with $N, N$-dimethylformamide (DMF). Figure 6c shows the solution extracted from each support. The quantity of indigo produced from each support is shown in Fig. 6d. The productivity with the reused support was similar to that with the pristine support, implying that the reused support retained its capability for bacterial immobilization after the immobilization/ detachment process. Thus, our reversible immobilization method uniquely allows us to reuse supports, even for different chemical reactions, via the immobilization of different bacterial cells.

\section{Discussion}

Immobilization of biocatalysts simplifies product separation, stabilizes biocatalysts, and enables the repeated or continuous use of biocatalysts, which are typically expensive to produce $[12,13]$. However, they are usually discarded, together with the supports, after a reaction. In protein immobilization, many techniques for reversible immobilization of enzymes (e.g. lipase, amyloglucosidase, glucoamylase, and aminoacylase) have been studied to enable the regeneration and reuse of support materials [31-35]. Additionally, with regard to bacterial cell immobilization, reversibility should be beneficial. However, the reuse of gel supports is impossible after their use in entrapment immobilization, which is most frequently employed for bacterial cells. Biofilm reactors are also used in the production of valuable compounds, such as alcohols and organic acids, not just in wastewater treatment $[15,36,37]$. These bioreactors use biofilms formed on support materials as immobilized microbial cells $[15,38]$. Once biofilms are formed, it is difficult to completely detach them from supports by simple treatments. Therefore, when catalytic activity decreases or a chemical reaction has to be switched for another one, the support with biofilms would be discarded and a new biofilm would be reconstructed on the fresh support. However, a long startup time is required to rebuild an active biofilm. 
In this study, we found that the stickiness of the AtaA molecule is drastically diminished at a lower ionic strength and is completely lost in $\mathrm{dH}_{2} \mathrm{O}$ (Fig. 1). Cell adhesion mediated by AtaA also depends on ionic strength in the same manner as the AtaA molecule, and even bacterial cells previously adhered to supports through AtaA can be detached in $\mathrm{dH}_{2} \mathrm{O}$ (Figs. 2, 3). Based on this adhesion property, we have established a reversible immobilization method for microbial cells (Fig. 4) and demonstrated the reuse of both cells and supports by means of this reversible immobilization (Figs. 5, 6).

Cells immobilized with AtaA can be detached from supports by a simple manipulation involving a $\mathrm{dH}_{2} \mathrm{O}$ wash and active cells can be quickly immobilized onto the same previously used support. Because this method is not based on the characteristics of support materials but the unique adhesion property of AtaA, various materials can be employed as reusable supports. For example, supports that have a structure with pores, fibers, or slits for a large surface area and are formed in a combined unit or integrated into a reactor vessel might be used.

In our new reversible immobilization method, both cells and supports can be reused for different types of chemical reactions. Three patterns can be considered about reused processes; (1) used cells are re-immobilized onto a new support, (2) fresh cells are immobilized onto a used support, and (3) used cells are re-immobilized onto a used support. In other words, one of or both of cells and a support are reused. It is expensive to grow bacterial cells on a medium containing many kinds of chemicals, such as nutrients, inducers, and antibiotics, using energy for sterilization, agitation, aeration, and temperature control. In this study, we demonstrated that bacterial cells can be reused for a different type of chemical reaction after a simple induction or reactivation step. We can choose a different support material that is suitable for the subsequent reaction. For example, we used polyurethane foam for the first reaction of ester hydrolysis in a buffer and steel wool for the second reaction of toluene degradation in a gas phase. In addition, the polyurethane foam can also be reused for a different reaction, such as indigo production, after immobilization of a different bacterial strain. The reuse of support material mitigates problems caused by the use of support materials, such as the cost and waste of support materials. Reversible microbial cell immobilization would make bioreactors and bioprocesses simpler, more efficient, more cost-effective, and more convenient.

\section{Conclusions}

In summary, we found that the stickiness of isolated AtaA PSD and cell adhesion mediated by AtaA are drastically diminished in deionized water and that deionized water even detaches bacterial cells previously adhered to support in a salt solution. Using this phenomenon, we invented a unique reversible immobilization method that allows us to reuse bacterial cells and supports for different chemical reactions by a simple manipulation involving a $\mathrm{dH}_{2} \mathrm{O}$ wash. This method for the immobilization of bacterial cells using AtaA would make bioprocesses more cost-effective and enhance their commercial use for environmentally friendly chemical productions.

\section{Methods}

\section{Bacterial strains and culture conditions}

The bacterial strains used in this study are detailed in Table 1 . These bacterial strains were grown as described previously [20].

\section{Enzyme-linked immunosorbent assay (ELISA)}

AtaA PSD was isolated and purified from the Tol 5 derivative strain 4140 [27] harboring p3CAtaA plasmid (Tol 5 4140 (p3CAtaA)), as described previously [26]. Twentyfive microliters of the purified AtaA PSD $(10 \mu \mathrm{g} / \mathrm{mL})$ and an equal volume of $\mathrm{KCl}$ solution were added to each well of 96-well PS plates (353072; Becton, Dickinson and Company, NJ) or 96-well glass plates (FB-96; Nippon Sheet Glass Company, Ltd., Tokyo, Japan) and incubated at $28{ }^{\circ} \mathrm{C}$ for adsorption. After a 2-h incubation, the solution was removed by a micropipette and each well was gently rinsed three times by removing and replacing $200 \mu \mathrm{L}$ of PBS-T. Then, $200 \mu \mathrm{L}$ of PBS-T containing $2 \%$ skim milk was added to each well and incubated for $30 \mathrm{~min}$ for blocking. Thereafter, the protein adsorbed to the well surface was treated with anti- $\mathrm{AtaA}_{699-1014}$ antiserum [20] at a 1:10,000 dilution in PBS-T for 30 min and subsequently with a HRP-conjugated anti-rabbit antibody at

Table 1 Bacterial strains and plasmids used in this study

\begin{tabular}{|c|c|c|}
\hline Strains or plasmids & Description & Reference \\
\hline \multicolumn{3}{|l|}{ Acinetobacter } \\
\hline sp. Tol 5 & Wild type strain & {$[21]$} \\
\hline sp. Tol 54140 & Unmarked $\triangle a t a A$ mutant of Tol 5 & [27] \\
\hline $\begin{array}{l}\text { sp. Tol } 54140 \\
\text { (p3CAtaA) }\end{array}$ & $\begin{array}{l}\text { Tol } 54140 \text { harboring p3CAtaA } \\
\text { plasmid }\end{array}$ & {$[26]$} \\
\hline baylyi ADP1 & Wild type strain: ATCC 33305 & {$[40]$} \\
\hline baylyi ADP1 (pAtaA) & ADP1 harboring pAtaA plasmid & [20] \\
\hline sp. ST-550 & Indigo productive strain & [30] \\
\hline sp. ST-550 (pAtaA) & ST-550 harboring pAtaA plasmid & {$[22]$} \\
\hline \multicolumn{3}{|l|}{ Plasmids } \\
\hline pARP3 & $\begin{array}{l}\text { E. coli-Acinetobacter shuttle } \\
\text { expression vector, araC-P }{ }_{B A D^{\prime}} \\
G^{r}, \mathrm{Amp}^{r}\end{array}$ & {$[20]$} \\
\hline pAtaA & $\begin{array}{l}\text { ataA-expression vector, } \\
\text { pARP3::ataA }\end{array}$ & {$[20]$} \\
\hline p3CAtaA & $\begin{array}{l}\text { 3CataA-expression vector, } \\
\text { pARP3::3CataA }\end{array}$ & [26] \\
\hline
\end{tabular}


a 1:10,000 dilution in PBS-T for 30 min. Finally, the wells were rinsed five times with PBS-T, and $100 \mu \mathrm{L}$ of substrate solution [ELISA POD Substrate TMB Solution (Popular); Nacalai Tesque, Kyoto, Japan] was added, followed by a 15-min incubation at room temperature. The reaction was stopped by the addition of $100 \mu \mathrm{L}$ of $1.0 \mathrm{M} \mathrm{H}_{2} \mathrm{SO}_{4}$ and the absorbance at $450 \mathrm{~nm}\left(\mathrm{~A}_{450}\right)$ was measured using a microplate reader (ARVO X3; PerkinElmer, Inc., MA).

\section{Quartz crystal microbalance}

The adhesiveness of AtaA PSD was measured using a QCM system (AFFINIX Q8; ULVAC, Kanagawa, Japan) as described previously [26] with a slight modification. A gold-coated electrode (QCM01S-01; ULVAC) was cleaned with piranha solution $\left(\mathrm{H}_{2} \mathrm{SO}_{4}: 30 \% \mathrm{H}_{2} \mathrm{O}_{2}=3: 1\right)$ and equilibrated with $98 \mu \mathrm{L}$ of $\mathrm{dH}_{2} \mathrm{O}$ at $25^{\circ} \mathrm{C}$. After the equilibration, $1 \mu \mathrm{L}$ of AtaA PSD solution $(0.1 \mathrm{mg} / \mathrm{mL})$ was added and the frequency change was measured for $5 \mathrm{~min}$. Subsequently, $1 \mu \mathrm{L}$ of $100 \mathrm{mM} \mathrm{KCl}$ solution (final concentration $=1 \mathrm{mM}$ ) was added and the measurement was continued.

\section{Cell attachment and detachment assays using well plates}

For a cell attachment assay, the harvested cells were washed three times with $\mathrm{dH}_{2} \mathrm{O}$ and suspended in $\mathrm{KCl}$ solutions of various concentrations or $\mathrm{dH}_{2} \mathrm{O}$ at an $\mathrm{OD}_{660}$ of 0.5 . The cell suspensions $(200 \mu \mathrm{L}$ each) were placed into wells of 96-well PS or glass plates. After a 2-h incubation at $28{ }^{\circ} \mathrm{C}$ without shaking, the cell suspensions were removed by a micropipette and each well was rinsed three times with $200 \mu \mathrm{L}$ of $\mathrm{KCl}$ solution of each concentration or $\mathrm{dH}_{2} \mathrm{O}$. The immobilized cells were stained with $200 \mu \mathrm{L}$ of $0.1 \%$ crystal violet solution for $15 \mathrm{~min}$. After three rinses with $200 \mu \mathrm{L}$ of $\mathrm{KCl}$ solution of each concentration or $\mathrm{dH}_{2} \mathrm{O}$, the dye was eluted from the cells with $200 \mu \mathrm{L}$ of $70 \%$ ethanol, and the absorbance at $590 \mathrm{~nm}$ $\left(\mathrm{A}_{590}\right)$ of the elution was measured by a microplate reader.

For a cell detachment assay, each well was rinsed three times with $200 \mu \mathrm{L}$ of $100 \mathrm{mM} \mathrm{KCl}$ solution or $\mathrm{dH}_{2} \mathrm{O}$ using a micropipette. The remaining cells were quantified by crystal violet staining as described above. For reattachment, the cells detached by rinsing each well with $\mathrm{dH}_{2} \mathrm{O}$ were collected by centrifugation, resuspended in $100 \mathrm{mM} \mathrm{KCl}$ solution at an $\mathrm{OD}_{660}$ of 0.5 , and added to a new well for the next immobilization cycle.

\section{Immobilization of bacterial cells onto support materials}

Polyurethane foam with a specific surface area of $37.5 \mathrm{~cm}^{2} / \mathrm{cm}^{3}$ (CFH-30; Inoac Corporation, Nagoya, Japan) in the shape of a cube $\left(1 \mathrm{~cm}^{3}\right)$ was used as a sponge support. The steel wool used in this study was the same as that previously used [25], which was purchased from Handy Crown (Tokyo, Japan).
To immobilize bacterial cells onto the polyurethane foam support, cells were suspended in $100 \mathrm{mM} \mathrm{KCl}$ solution in a $100-\mathrm{mL}$ Erlenmeyer flask. The value of the $\mathrm{OD}_{660}$ was adjusted to 2.0 for the visualization of the cell detachment from the support and for the analysis of the time profile of cell immobilization or to 1.0 for use in chemical reactions. Pieces of the support were placed into the cell suspension and shaken at $115 \mathrm{rpm}$ at 28 or $30{ }^{\circ} \mathrm{C}$ for $10-30 \mathrm{~min}$. For analysis of the time profile of cell immobilization, the $\mathrm{OD}_{660}$ of the cell suspension was measured periodically. The immobilization ratio of the cells was calculated from the following equation:

Immobilization ratio (\%)

$$
=\left(\mathrm{OD}_{660 \text { initial }}-\mathrm{OD}_{660 \text { after shaking }}\right) / \mathrm{OD}_{660 \text { initial }} \times 100 \text {. }
$$

To immobilize bacterial cells onto the steel wool support, the cells detached from the three pieces of the polyurethane foam support used for the esterase reaction were resuspended in $30 \mathrm{~mL}$ of BS medium [39] in a 100$\mathrm{mL}$ Erlenmeyer flask. Into this cell suspension, $300 \mathrm{mg}$ of the steel wool support was placed and shaken at $115 \mathrm{rpm}$ at $28^{\circ} \mathrm{C}$ for $1 \mathrm{~h}$.

\section{Flow cytometry}

Bacterial cells before and after the cell immobilization/ detachment test were resuspended in PBS containing 4\% paraformaldehyde and incubated at room temperature for 15 min. The samples were washed with PBS and treated with anti-AtaA $\mathrm{A}_{69-1014}$ antiserum diluted 1:10,000 in PBS. After a 1-h incubation at room temperature, the samples were washed twice with NET buffer $(150 \mathrm{mM} \mathrm{NaCl}$, 5 mM EDTA, $50 \mathrm{mM}$ Tris- $\mathrm{HCl}, 0.05 \%$ Triton $\mathrm{X}-100, \mathrm{pH}$ 7.6) and treated with Alexa Fluor 488-conjugated antirabbit antibody (Cell Signaling Technology, MA) diluted 1:500 in NET buffer for $30 \mathrm{~min}$. Finally, the samples were resuspended in $\mathrm{dH}_{2} \mathrm{O}$, and the fluorescence was measured by FACS Canto II (Becton, Dickinson and Company, NJ).

\section{Chemical reactions by immobilized bacteria}

For the measurement of cell-bound esterase activity, cells immobilized on plate wells were reacted with $1.9 \mathrm{mM}$ 4-nitrophenyl butyrate (4-NPB) in $200 \mu \mathrm{L}$ reaction buffer (1.1\% Triton X-100, $50 \mathrm{mM}$ 3,3-dimethylglutaric acid, $50 \mathrm{mM}$ Tris, $50 \mathrm{mM}$ 2-amino-2-methyl-1,3-propanediol) at $28{ }^{\circ} \mathrm{C}$ for $30 \mathrm{~min}$. Triton $\mathrm{X}-100$ was eliminated from the reaction buffer when the esterase activity of Tol 5 was measured. The $\mathrm{A}_{405}$ of 4-nitrophenol produced by the reaction was measured by a microplate reader. To measure the esterase activity of cells immobilized on the polyurethane support, a piece of the support with the immobilized cells was placed into $3 \mathrm{~mL}$ of the reaction buffer in a test tube and incubated at $28^{\circ} \mathrm{C}$ for $10 \mathrm{~min}$. 
For indigo production, a piece of polyurethane foam support with immobilized cells was transferred into a 3 - $\mathrm{mL}$ reaction solution $(1 \mathrm{mM}$ indole, $1 \% \mathrm{DMF}, 40 \mathrm{mM}$ potassium phosphate buffer, $\mathrm{pH}$ 7.0) in a test tube and incubated at $30{ }^{\circ} \mathrm{C}$ for $12 \mathrm{~h}$. Indigo produced from indole was extracted with DMF, and its concentration was determined using $\mathrm{A}_{610}$ measurement.

For toluene degradation, bacterial cells immobilized on steel wool were placed in a $25-\mathrm{mL}$ vial capped by a butyl rubber septum. The reaction was started by injecting $1 \mu \mathrm{L}$ of toluene into the vial using a gastight syringe (MSGFN100; ITO Corporation, Fuji, Japan). The toluene concentration was measured using GC/MS, which comprised a GC system (GC7820A; Agilent Technologies, Santa Clara, CA) coupled to a MS detector (MSD 5975; Agilent Technologies), equipped with a Rtx-200 capillary column (30 $\mathrm{m} \times 0.32 \mathrm{~mm} \times 0.5 \mu \mathrm{m}$; RESTEC, Bellefonte, PA). Gas sample $(50 \mu \mathrm{L})$ was taken from a vial and injected into the GC/MS system using the gastight syringe. The split ratio and the flow rate of helium were set at 10:1 and $2 \mathrm{~mL} /$ min, respectively. The operating program started with an isocratic step at $90{ }^{\circ} \mathrm{C}$ for $1 \mathrm{~min}$, followed by temperature ramping of $25{ }^{\circ} \mathrm{C} / \mathrm{min}$ to the final temperature at $120{ }^{\circ} \mathrm{C}$, then ion fragments of $\mathrm{m} / \mathrm{z}=65$ and $\mathrm{m} / \mathrm{z}=91$ were monitored on the selected ion monitoring mode. The peak, which showed toluene, was detected at a retention time of $1.4 \mathrm{~min}$. The degradation ratio of toluene was calculated from the ratio of the peak area at each time to that at $0 \mathrm{~min}$.

\section{Additional files}

Additional file 1. Detachment of adhered ADP1 ( $p A t a A)$ cells from a polyurethane support by washing in $\mathrm{dH}_{2} \mathrm{O}$. The polyurethane supports were put into the ADP1 (pAtaA) cell suspension in $100 \mathrm{mM} \mathrm{KCl}$ solution and were incubated at $28^{\circ} \mathrm{C}$ with shaking at $115 \mathrm{rpm}$. After incubation for $10 \mathrm{~min}$, the supports were retrieved and lightly washed with $100 \mathrm{mM} \mathrm{KCl}$ solution. Then, the supports were picked up with tweezers and shaken in $100 \mathrm{~mL}$ of $\mathrm{dH}_{2} \mathrm{O}$ for $1 \mathrm{~min}$. Note that the white grains in the $\mathrm{dH}_{2} \mathrm{O}$ are detached cells.

Additional file 2. Detachment of adhered ADP1 (pAtaA) cells from a polyurethane support by washing in $100 \mathrm{mM} \mathrm{KCl}$ solution. The polyurethane supports were put into the ADP1 (pAtaA) cell suspension in $100 \mathrm{mM} \mathrm{KCl}$ solution and were incubated at $28^{\circ} \mathrm{C}$ with shaking at $115 \mathrm{rpm}$. After incubation for $10 \mathrm{~min}$, the supports were retrieved and lightly washed with $100 \mathrm{mM} \mathrm{KCl}$ solution. Then, the supports were picked up with tweezers and shaken in $100 \mathrm{~mL}$ of $100 \mathrm{mM} \mathrm{KCl}$ solution for $1 \mathrm{~min}$.

\begin{abstract}
Abbreviations
TAA: trimeric autotransporter adhesion; PSD: passenger domain; TM: transmembrane anchor; HRV 3C: human rhinovirus 3C; $\mathrm{dH}_{2} \mathrm{O}$ : deionized water; ELISA: enzyme-linked immunosorbent assay; HRP: horseradish peroxidase; POD: peroxidase; QCM: quartz crystal microbalance; 4-NPB: 4-nitrophenyl butyrate; BS: basal salt; GC/MS: gas chromatography-mass spectrometry; DMF: N,N-dimethylformamide; PS: polystyrene.
\end{abstract}

\section{Authors' contributions}

The manuscript was written through contributions of $\mathrm{SY}, \mathrm{YO}, \mathrm{HN}$ and $\mathrm{KH}$. All authors read and approved the final manuscript.
Acknowledgements

Not applicable.

\section{Competing interests}

A patent application has been filed in relation to this work (JP2014/056966).

Availability of data and materials

All data generated or analyzed during this study are included in this published article and its additional files.

\section{Funding}

This work was supported by the Advanced Low Carbon Technology Research and Development Program (ALCA) of the Japan Science and Technology Agency (JST) and by the Program for Leading Graduate Schools "Integrative Graduate Education and Research in Green Natural Sciences", MEXT, Japan.

\section{Publisher's Note}

Springer Nature remains neutral with regard to jurisdictional claims in published maps and institutional affiliations.

Received: 12 February 2017 Accepted: 10 July 2017

Published online: 18 July 2017

\section{References}

1. Taher E, Chandran K. High-rate, high-yield production of methanol by ammonia-oxidizing bacteria. Environ Sci Technol. 2013;47:3167-73.

2. Fukuda H, Hama S, Tamalampudi S, Noda H. Whole-cell biocatalysts for biodiesel fuel production. Trends Biotechnol. 2008;26:668-73.

3. Pollard DJ, Woodley JM. Biocatalysis for pharmaceutical intermediates: the future is now. Trends Biotechnol. 2007;25:66-73.

4. Wang SN, Xu P, Tang HZ, Meng J, Liu XL, Qing C. "Green" route to 6-hydroxy-3-succinoyl-pyridine from (S)-nicotine of tobacco waste by whole cells of a Pseudomonas sp. Environ Sci Technol. 2005:39:6877-80

5. Schmid A, Dordick JS, Hauer B, Kiener A, Wubbolts M, Witholt B. Industrial biocatalysis today and tomorrow. Nature. 2001:409:258-68.

6. Lee SY, Kim HU. Systems strategies for developing industrial microbial strains. Nat Biotechnol. 2015;33:1061-72.

7. Choi SY, Park SJ, Kim WJ, Yang JE, Lee H, Shin J, Lee SY. One-step fermentative production of poly(lactate-co-glycolate) from carbohydrates in Escherichia coli. Nat Biotechnol. 2016:34:435-40.

8. Cheong S, Clomburg JM, Gonzalez R. Energy- and carbon-efficient synthesis of functionalized small molecules in bacteria using non-decarboxylative Claisen condensation reactions. Nat Biotechnol. 2016;34:556-61.

9. DeLoache WC, Russ ZN, Narcross L, Gonzales AM, Martin VJ, Dueber JE. An enzyme-coupled biosensor enables (S)-reticuline production in yeast from glucose. Nat Chem Biol. 2015;11:465-71.

10. Paddon CJ, Westfall PJ, Pitera DJ, Benjamin K, Fisher K, McPhee D, Leavell MD, Tai A, Main A, Eng D, et al. High-level semi-synthetic production of the potent antimalarial artemisinin. Nature. 2013:496:528-32.

11. Hara KY, Araki M, Okai N, Wakai S, Hasunuma T, Kondo A. Development of bio-based fine chemical production through synthetic bioengineering. Microb Cell Factories. 2014;13:173.

12. Junter $G A$, Jouenne T. Immobilized viable microbial cells: from the process to the proteome... or the cart before the horse. Biotechnol Adv. 2004;22:633-58.

13. Hartmeier W. Immobilized biocatalysts_-from simple to complex systems. Trends Biotechnol. 1985:3:149-53.

14. Gong JS, Lu ZM, Li H, Shi JS, Zhou ZM, Xu ZH. Nitrilases in nitrile biocatalysis: recent progress and forthcoming research. Microb Cell Factories. 2012;11:142.

15. Qureshi N, Annous BA, Ezeji TC, Karcher P, Maddox IS. Biofilm reactors for industrial bioconversion processes: employing potential of enhanced reaction rates. Microb Cell Factories. 2005;4:24.

16. Smidsrod O, Skjakbraek G. Alginate as immobilization matrix for cells. Trends Biotechnol. 1990;8:71-8.

17. Klein J, Ziehr H. Immobilization of microbial-cells by adsorption. J Biotechnol. 1990;16:1-16. 
18. Carballeira JD, Quezada MA, Hoyos P, Simeo Y, Hernaiz MJ, Alcantara AR, Sinisterra JV. Microbial cells as catalysts for stereoselective red-ox reactions. Biotechnol Adv. 2009;27:686-714.

19. Cassidy MB, Lee H, Trevors JT. Environmental applications of immobilized microbial cells: a review. J Ind Microbiol Biotechnol. 1996;16:79-101.

20. Ishikawa M, Nakatani H, Hori K. AtaA, a new member of the trimeric autotransporter adhesins from Acinetobacter sp. Tol 5 mediating high adhesiveness to various abiotic surfaces. PLoS ONE. 2012;7:e48830.

21. Hori K, Yamashita S, Ishii S, Kitagawa M, Tanji Y, Unno H. Isolation, characterization and application to off-gas treatment of toluene-degrading bacteria. J Chem Eng Japan. 2001;39:175-84.

22. Ishikawa M, Shigemori K, Hori K. Application of the adhesive bacterionanofiber AtaA to a novel microbial immobilization method for the production of indigo as a model chemical. Biotechnol Bioeng. 2014;111:16-24.

23. Linke D, Riess T, Autenrieth IB, Lupas A, Kempf VA. Trimeric autotransporter adhesins: variable structure, common function. Trends Microbiol. 2006;14:264-70.

24. Bassler J, Hernandez Alvarez B, Hartmann MD, Lupas AN. A domain dictionary of trimeric autotransporter adhesins. Int J Med Microbiol. 2015;305:265-75.

25. Hori K, Ohara Y, Ishikawa M, Nakatani H. Effectiveness of direct immobilization of bacterial cells onto material surfaces using the bacterionanofiber protein AtaA. Appl Microbiol Biotechnol. 2015;99:5025-32.

26. Yoshimoto S, Nakatani H, Iwasaki K, Hori K. An Acinetobacter trimeric autotransporter adhesin reaped from cells exhibits its nonspecific stickiness via a highly stable 3D structure. Sci Rep. 2016;6:28020.

27. Ishikawa M, Hori K. A new simple method for introducing an unmarked mutation into a large gene of non-competent Gram-negative bacteria by FLP/FRT recombination. BMC Microbiol. 2013;13:86.

28. Koiwai K, Hartmann MD, Linke D, Lupas AN, Hori K. Structural basis for toughness and flexibility in the C-terminal passenger domain of an Acinetobacter trimeric autotransporter adhesin. J Biol Chem. 2016;291:3705-24.

29. Doukyu N, Toyoda K, Aono R. Indigo production by Escherichia coli carrying the phenol hydroxylase gene from Acinetobacter sp. strain ST-550 in a water-organic solvent two-phase system. Appl Microbiol Biotechnol. 2003;60:720-5.

30. Doukyu N, Nakano T, Okuyama Y, Aono R. Isolation of an Acinetobacter sp. ST-550 which produces a high level of indigo in a water-organic solvent two-phase system containing high levels of indole. Appl Microbiol Biotechnol. 2002:58:543-6.
31. Mateo C, Abian O, Fernandez-Lafuente R, Guisan JM. Reversible enzyme immobilization via a very strong and nondistorting ionic adsorption on support-polyethylenimine composites. Biotechnol Bioeng. 2000;68:98-105.

32. Rueda N, Dos Santos JC, Rodriguez MD, Albuquerque TL, Barbosa O, Torres $\mathrm{R}$, Ortiz C, Fernandez-Lafuente R. Reversible immobilization of lipases on octyl-glutamic agarose beads: a mixed adsorption that reinforces enzyme immobilization. J Mol Cat B. 2016;128:10-8.

33. Saylan $Y$, Uzun L, Denizli A. Alanine functionalized magnetic nanoparticles for reversible amyloglucosidase immobilization. Ind Eng Chem Res. 2015:54:454-61.

34. Wang J, Zhao G, Li Y, Liu X, Hou P. Reversible immobilization of glucoamylase onto magnetic chitosan nanocarriers. Appl Microbiol Biotechnol. 2013;97:681-92.

35. Chibata I, Tosa T. Industrial applications of immobilized enzymes and immobilized microbial cells. In: Wingard LB, Katchalski-Katzir E, Leon G, editors. Applied biochemistry and bioengineering. London: Academic; 1976. p. 329-57.

36. Liu D, Chen Y, Ding FY, Zhao T, Wu JL, Guo T, Ren HF, Li BB, Niu HQ, Cao $Z$, et al. Biobutanol production in a Clostridium acetobutylicum biofilm reactor integrated with simultaneous product recovery by adsorption. Biotechnol Biofuels. 2014:7:5.

37. Zhang F, Ding J, Zhang Y, Chen M, Ding ZW, van Loosdrecht MC, Zeng RJ. Fatty acids production from hydrogen and carbon dioxide by mixed culture in the membrane biofilm reactor. Water Res. 2013;47:6122-9.

38. O'Toole G, Kaplan HB, Kolter R. Biofilm formation as microbial development. Annu Rev Microbiol. 2000:54:49-79.

39. Ishii S, Unno H, Miyata S, Hori K. Effect of cell appendages on the adhesion properties of a highly adhesive bacterium, Acinetobacter sp. Tol 5. Biosci Biotechnol Biochem. 2006;70:2635-40.

40. Metzgar D, Bacher JM, Pezo V, Reader J, Doring V, Schimmel P, Marliere $P$, de Crecy-Lagard V. Acinetobacter sp. ADP1: an ideal model organism for genetic analysis and genome engineering. Nucleic Acids Res. 2004;32:5780-90.

\section{Submit your next manuscript to BioMed Central and we will help you at every step:}

- We accept pre-submission inquiries

- Our selector tool helps you to find the most relevant journal

- We provide round the clock customer support

- Convenient online submission

- Thorough peer review

- Inclusion in PubMed and all major indexing services

- Maximum visibility for your research

Submit your manuscript at www.biomedcentral.com/submit
BioMed Central 